\title{
Eggshell Membrane Microcolumn Solid-Phase Extraction and Determination of Trace Gold in Geological Samples by Inductively Coupled Plasma Mass Spectrometry
}

\author{
Xianzhong Cheng ${ }^{\mathrm{a} *}$, Jin Liu ${ }^{\mathrm{a}}$, Xiaoli Yang ${ }^{\mathrm{b}}$, Hongmei Chen ${ }^{\mathrm{a}}$, and Yourong Wang \\ a School of Chemical and Environmental Engineering, \\ Wuhan Polytechnic University, Wuhan 430023, P.R. China \\ b Wuhan Institute of Geology and Mineral Resources, Wuhan 430205, P.R. China
}

\section{INTRODUCTION}

Gold is a noble metal with an important role in technology and the development of national economies. In general, gold occurs in a separate mineral phase that tends to be distributed heterogeneously with very low natural abundance in geological samples (1). The Au content is approximately $4.0 \mathrm{ng} \mathrm{g}^{-1}$ in basic rocks, $1.0 \mathrm{ng} \mathrm{g}^{-1}$ in soil, $0.05 \mathrm{ng} \mathrm{mL}^{-1}$ in seawater, and $0.2 \mathrm{ng} \mathrm{mL}^{-1}$ in river water (2). Up to now, the determination of gold is a challenge for analysts because modern instrumental techniques, such as atomic absorption spectrometry (AAS) (3), electrothermal atomic absorption spectrometry (ETAAS) $(4,5)$, atomic fluorescence spectrometry (AFS) (6), and inductively coupled plasma mass spectrometry/atomic emission spectrometry (ICP-MS/AES) $(7,8)$, suffer from matrix interferences in most real samples. Therefore, a separation and preconcentration step is often necessary for sensitive, accurate, and interference-free determination.

In recent years, many studies have focused on solid-phase extraction (SPE) for the separation and preconcentration of trace-metal elements, organic pollutants, organometals, and proteins in analytical chemistry (9). Compared to traditional liquid-liquid extraction techniques, SPE has many advantages, such as rapid phase separa-

\footnotetext{
*Corresponding autbor.

E-mail: xzcheng@whpu.edu.cn; whcxz502@163.com

Tel: $+86-27-83943956$

Fax: + 86-27-83956762
}

\begin{abstract}
A chicken eggshell membrane (ESM) was used as a solid-phase extraction adsorbent for the separation and preconcentration in combination with inductively coupled plasma-mass spectrometry (ICP-MS) for the determination of trace gold in geological samples. Gold (Au) was quantitatively separated and preconcentrated in $1.2 \mathrm{~mol} \mathrm{~L}^{-1} \mathrm{HCl}$ at a sample flow rate of $2.0 \mathrm{~mL} \mathrm{\textrm {min } ^ { - 1 }}$ using the ESM microcolumn system. The gold adsorbed on the microcolumn was effectively eluted with a mixture of $1 \%$ thiourea and $0.12 \mathrm{~mol} \mathrm{~L}^{-1} \mathrm{HCl}$. The effects of acid concentration sample flow rate and volume, eluent conditions and interfering ions were carefully investigated. The transition- and heavy-metal ions did not interfere with either the separation/preconcentration or the determination.

The limit of detection of the method for Au was $0.92 \mathrm{ng} \mathrm{L}^{-1}$. The method was validated using certified reference materials and applied to the determination of trace $\mathrm{Au}$ in geological samples with satisfactory results.
\end{abstract}

tion, higher enrichment factor, low organic solvent consumption, better repeatability, and the ability to couple with other on- or off-line detection techniques (10). A number of different sorbents have been investigated for the separation and preconcentration of trace gold, including resin (11-13), activated carbon (14), polymeric supports (15), nanometer materials $(16,17)$, and modified silica gel $(18,19)$.
Unfortunately, most of the abovementioned solid absorbents are expensive and harmful to the environment. Therefore, an investigation into the feasibility of the use of very inexpensive, easily obtainable and environmentally friendly adsorbent materials with high selectivity, stability, and extraction efficiency for SPE is of great interest to analysts. In recent years, natural biomass, such as chitosan $(20,21)$, thiol-cotton fibre (22), tree leaf powder (23), and silk fibroin (24), has attracted increasing attention in solid-phase extraction.

Eggshell membranes (ESM), a natural byproduct, are easily obtained in the food industry and possess an intricate lattice network of stable and water-insoluble fibres (25). Some characteristics of the ESM, such as their large surface area and special functional groups, including hydroxyl (-OH), sulfhydryl $(-\mathrm{SH})$, carboxyl $(-\mathrm{COOH})$ and aminol $\left(-\mathrm{NH}_{2}\right)$, imbue it with the ability to adsorb some metal ions. Thus, ESM shows great potential as a SPE adsorbent. A few applications of ESM have been reported for water-pollution and wastewater treatment, e.g., the elimination of heavy metal ions $(26,27)$ and biosorption of actinides (28). Additionally, ESM can be used for the adsorption of toxic dyes (29), immobilization support $(30,31)$, and as templates for synthesizing nanocrystals $(32,33)$. Recently, ESM have been successfully applied for solid-phase extraction, separation, preconcentration, and determination of $\mathrm{Cr}$ and As $(34,35)$.

In this work, we used ESM as a SPE adsorbent for the highly selec- 
tive separation and preconcentration of trace $\mathrm{Au}$ in $1.2 \mathrm{~mol} \mathrm{~L}^{-1} \mathrm{HCl}$ and its determination at the $\mathrm{ng}^{-1}$ level by inductively coupled plasma mass spectrometry, which has not been previously reported. The opticoncentration, eluent type, sample flow rate, amount of ESM and interfering ions for the quantitative recovery of trace $\mathrm{Au}$, were investigated. The results show that ESM can be used in SPE for the efficient separation and preconcentration of trace Au. The proposed method has been applied for the determination of the trace gold in three geological samples.

\section{EXPERIMENTAL}

\section{Instrumentation}

An X SeriesII ICP-MS system (Thermo Elemental Corporation, USA) with a concentric nebulizer (Meinhard) was used for analyte determination. The optimum ICPMS operation parameters are given in Table $\mathrm{I}$.

A Nicolet AVATAR 330 Fouriertransform infrared spectrometer (FT-IR) (Thermo Electron Corporation, USA) was used to identify the functional groups in the adsorbent ESM. mum conditions, including acid

A HL-2 peristaltic pump (Shanghai Qingpu Huxi Instrument Factory, Shanghai, P.R. China) was used in the separation and preconcentration processes. A home-made conical microcolumn $(70 \mathrm{~mm}$ length, $1000 \mu \mathrm{L}$ pipette tips), packed with ESM, was used in the separation and preconcentration. A minimum length of PTFE tubing with an i.d. of $0.5 \mathrm{~mm}$ was used for all connections.

A microwave sample digestion system, the MSD-2002A Closed-Vessel Microwave-Controlled Pressure System (Shanghai SINEO Microwave Chemistry Technology Co. Ltd., Shanghai, P.R. China), was used for the dissolution of the certified reference material.

\section{Standard Solutions and Reagents}

The stock standard solution of $1000 \mathrm{mg} \mathrm{L}^{-1}$ gold was purchased from the National Research Centre for Certified Reference Materials (National Research Centre for CRMs, Beijing, P.R. China). The working standard solutions of $100 \mu \mathrm{g} \mathrm{L}^{-1}$ and $1 \mathrm{mg} \mathrm{L}^{-1}$ were prepared daily by adequate dilution of the stock solution with $1.2 \mathrm{~mol} \mathrm{~L}^{-1}$ HCl.

TABLE I

ICP-MS Operating Parameters

\begin{tabular}{lr}
\hline Plasma power & $1350 \mathrm{~W}$ \\
Cool argon flow rate & $13 \mathrm{~L} \mathrm{~min}^{-1}$ \\
Auxiliary argon flow rate & $0.76 \mathrm{~L} \mathrm{~min}^{-1}$ \\
Nebuliser argon flow rate & $1.02 \mathrm{~L} \mathrm{~min}^{-1}$ \\
Sampler/Skimmer cone & $\mathrm{Ni} \mathrm{cone}$ \\
Sampling volume & $1.0 \mathrm{~L} \mathrm{~min}{ }^{-1}$ \\
Sampling depth & $7.8 \mathrm{~mm}$ \\
Sampling pattern & Quantitative \\
Scanning mode & Jump peak \\
Measure point/peak & 3 \\
Repeated time & 3 \\
Quality resolution & $0.65-0.8 \mu$ \\
Isotope & $197 \mathrm{Au}$ \\
\hline
\end{tabular}

The elution solution of $1.0 \%$ thiourea $(\mathrm{m} / \mathrm{v})$ was made by dissolving $5.0 \mathrm{~g}$ of thiourea in $0.12 \mathrm{~mol} \mathrm{~L}^{-1} \mathrm{HCl}$ solution and made up to $500 \mathrm{~mL}$ in a volumetric flask.

All reagents were of analytical grade unless otherwise stated. Doubly deionized water (DDW) obtained from a Milli-Q ${ }^{\mathrm{TM}}$ water purification system (Millipore Corporation, Bedford, MA, USA) with a metered resistance of $18 \mathrm{M} \Omega \mathrm{cm}$ was used throughout. All vessels were cleaned by soaking in 10\% nitric acid and rinsed with distilled water prior to use.

The certified reference materials GBW07244, GBW07246, and GBW07293 (National Research Centre for CRM's, Beijing, P.R. China) were used to evaluate the accuracy of the present method.

\section{Preparation of Eggshell Membrane}

Eggshells were collected from a campus breakfast shop. They were first washed thoroughly in tap water to completely remove the albumen and then rinsed with deionized water. The washed eggshell was immersed in a $10 \%$ acetic acid at $25^{\circ} \mathrm{C}$ for 2 hours to dissolve the mineral shell. Next, the eggshell membrane was cleaned with deionized water until no residual acid was detected. The eggshell membrane was dried at $45^{\circ} \mathrm{C}$ for 5 hours, ground to a powder with a mortar and pestle, and then stored for future use as a column packing material.

\section{Microcolumn Preparation}

The SPE column was made from a $1000 \mu \mathrm{L}$ pipette tip $(70 \mathrm{~mm}$ length, i.d. $0.6 \times 7 \mathrm{~mm})$. The conical microcolumn was filled with approximately $120 \mathrm{mg}$ of ESM biosorbent into an empty pipette tip. To avoid loss of ESM when the sample solution passes through the conical microcolumn, a small portion of glass wool was used to 
block both ends of the conical microcolumn. The wide end of the microcolumn was directly connected to a peristaltic pump with tubing to form the preconcentration system. Before use, $1.2 \mathrm{~mol} \mathrm{~L}^{-1}$ $\mathrm{HCl}$ was passed through the microcolumn to clean and condition it. Thus, the desired flow rate was easily obtained.

\section{General Procedure for Precon- centration and Separation}

An aliquot of a sample solution containing $0.10 \mu \mathrm{g}$ Au was transferred into a $250-\mathrm{mL}$ beaker. The acidity was adjusted to the desired value with concentrated hydrochloric acid or nitric acid. The sample solution was diluted to $50 \mathrm{~mL}$ with DDW before use. The solution was passed through the microcolumn by a peristaltic pump at a flow rate of $0.5-4.0 \mathrm{~mL} \mathrm{~min}{ }^{-1}$. Afterwards, the adsorbed Au was eluted consecutively with three $2.5 \mathrm{~mL}$ portions of the thiourea eluent solution at a

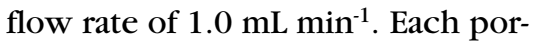
tion was collected in a $5-\mathrm{mL}$ volumetric flask and diluted to the mark with the thiourea eluent solution. The percent recovery of Au was calculated after the Au determination of the eluent by ICP-MS. A blank solution was prepared using the same procedure.

The calibration standard solutions of 0.01-500 $\mu \mathrm{g} \mathrm{L}^{-1} \mathrm{Au}$ were prepared from $100 \mu \mathrm{g} \mathrm{L}^{-1}$ and $1.0 \mathrm{mg} \mathrm{L}^{-1}$ of the Au working standard solution. These solutions were diluted to $25 \mathrm{~mL}$ with the thiourea eluent solution and submitted to determination by ICP-MS.

\section{Geological Sample Decomposi- tion Procedure}

A 0.5 -g sample was roasted for 3 hours in a muffle furnace at $600^{\circ} \mathrm{C}$. After roasting, the sample was transferred into a Teflon ${ }^{\circledR}$ vessel, and $8 \mathrm{~mL}$ of freshly prepared $a q u a$ regia was added to the vessel, which was then shaken to mix the solid and the liquid. The container was closed tightly, inserted into the microwave digestion system and subjected to the following digestion program: 5 minutes at $0.5 \mathrm{MPa}$, 10 minutes at $1.0 \mathrm{MPa}, 10$ minutes at $2.5 \mathrm{MPa}$, and 20 minutes at $0.2 \mathrm{MPa}$. After digestion, the vessel was removed and allowed to cool. The sample solution was transferred to a $250-\mathrm{mL}$ beaker and heated to near dryness on a hot plate at 100-120 ${ }^{\circ} \mathrm{C}$. Next, $25 \mathrm{~mL}$ of $1.2 \mathrm{~mol} \mathrm{~L}^{-1} \mathrm{HCl}$ was added to the beaker and warmed for 10 minutes on a hot plate at $100{ }^{\circ} \mathrm{C}$. Subsequently, the sample solution was cooled and filtered through blueband filter paper using vacuum filtration. The residue was thoroughly washed with $1.2 \mathrm{~mol} \mathrm{~L}^{-1} \mathrm{HCl}$. The final volume was made up to $50 \mathrm{~mL}$ with $1.2 \mathrm{~mol} \mathrm{~L}^{-1} \mathrm{HCl}$ solution. The geological certified reference materials (GBW07244, GBW07246, and GBW07293) were treated according to the above digestion method, as was a blank digestion sample. The separation and preconcentration procedure detailed above was then applied to the final solutions.

\section{RESULTS AND DISCUSSION}

\section{FT-IR Spectra of Eggshell Membrane}

The main organic constituents of eggshell membrane are highly cross-linked protein fibres of collagen, polypeptides, and amino acids
(36-38). These macromolecules contain hydrophilic functional groups, such as amino, hydroxyl, and carbonyl, which can interact with precious-metal and heavymetal elements. To investigate the functional groups in the eggshell membrane, FT-IR spectroscopy was employed. As shown in Figure 1, the peak positions are located at 3440 , 2925, 1631, 1386, and $1138 \mathrm{~cm}^{-1}$. The band at $3440 \mathrm{~cm}^{-1}$ can be attributed to the vibration of $\mathrm{O}-\mathrm{H}$ and $\mathrm{N}-\mathrm{H}$ in ESM fibres, and the $2925 \mathrm{~cm}^{-1}$ band with a weaker adsorption resulted from $\mathrm{C}-\mathrm{H}$ stretching vibrations. The band at $1631 \mathrm{~cm}^{-1}$ reflects the stretching of $\mathrm{C}=\mathrm{O}$ and bending of $\mathrm{N}-\mathrm{H}$. Bands at 1386, 1138 , and $1069 \mathrm{~cm}^{-1}$ correspond to the bending of $\mathrm{C}-\mathrm{H}$, stretching of $\mathrm{C}-\mathrm{O}$, and stretching of $\mathrm{C}-\mathrm{N}$, respectively. These results agree with the FT-IR results obtained by Pavia (39).

\section{Effect of Acid Concentration}

Sample digestion with aqua regia is one of the most suitable methods for converting gold from geological samples into their soluble complexes for analytical techniques. For this reason, different concentrations of hydrochloric and nitric acid were tested as a medium for the adsorption of $\mathrm{Au}$ ions in the range of 0.1-2.5 $\mathrm{mol} \mathrm{L}^{-1}$ at a flow rate of $2.0 \mathrm{~mL} \mathrm{~min}^{-1}$. Both acids were found to be suitable for the adsorption of Au. Figure 2 shows

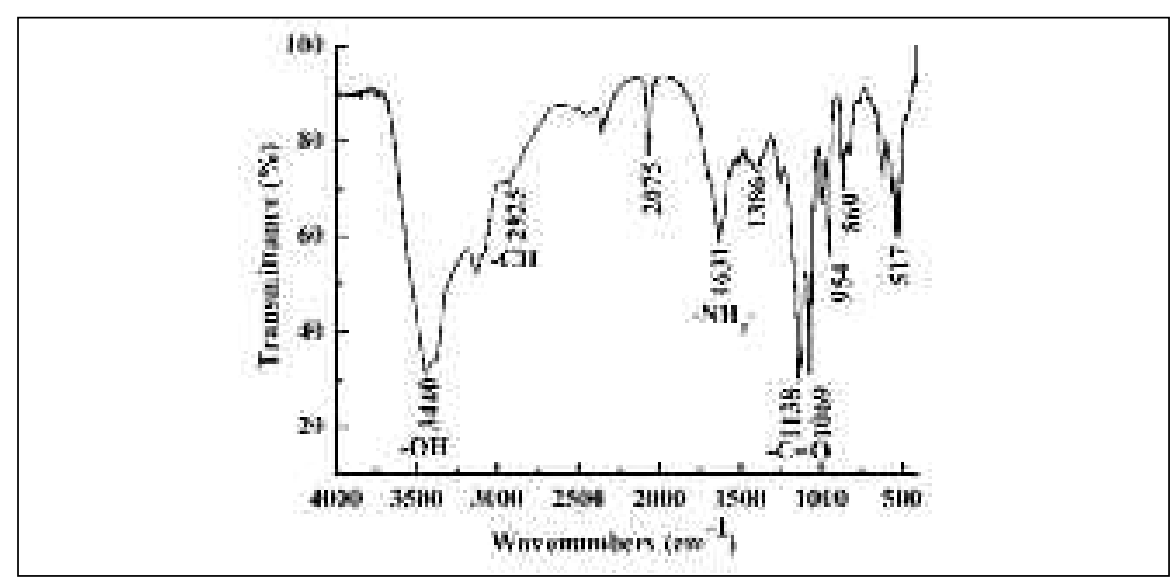

Fig. 1. FT-IR spectrum of eggshell membrane. 
the effects of acid concentration on the Au adsorption efficiency. The recovery percentage of Au was above $97 \%$ in $0.1-2.5 \mathrm{~mol} \mathrm{~L}^{-1} \mathrm{HCl}$ and 0.1-1.0 $\mathrm{mol} \mathrm{L}^{-1} \mathrm{HNO}_{3}$. In this work, a $1.2 \mathrm{~mol} \mathrm{~L}^{-1} \mathrm{HCl}$ solution was selected as the optimum concentration for subsequent experiments. In the strong acid medium of $1.2 \mathrm{~mol} \mathrm{~L}^{-1} \mathrm{HCl}, \mathrm{Cu}^{2+}, \mathrm{Co}^{2+}, \mathrm{Ni}^{2+}$, $\mathrm{Zn}^{2+}, \mathrm{Pb}^{2+}$, and $\mathrm{Fe}^{3+}$ were negligibly adsorbed, and the interference of these transition- and heavy-metal ions on the separation and preconcentration step was eliminated. In the experiments, we found that gold could also be adsorbed by ESM from $0.1-7.0 \%$ aqua regia.

The effect of acidic media on the gold adsorption mechanisms can be explained in two ways. First, soft metal ions such as $\mathrm{Au}^{3+}$ could selectively bond to the soft coordination sites (sulphur) of the-SH group according to the hard and soft principle of acids and bases (40). The sulphur donor atom of the $-\mathrm{SH}$ group is generally known to have a strong affinity towards Au. Second, the ESM has a complex porous structure made up of proteins, glycolipids, and carbohydrates $(41,42)$. The protein fiber of ESM is mainly derived from amino acids such as glycine and alanine, which contain many amino, hydroxyl, and carbonyl functional groups. Under strong acid conditions, a large number of amino and $\mathrm{N}$-acetyl groups of ESM can be protonated into the form of $-\mathrm{NH}_{3}{ }^{+}$and $-\mathrm{CO}-\mathrm{NH}_{2}{ }^{+}$(17), while $\mathrm{Au}(\mathrm{III})$ exists in the form of anionic $\left[\mathrm{AuCl}_{4}\right]^{-}$, which can be adsorbed to the surface of ESM by electrostatic interactions or ion association. The specific adsorption of ESM with Au has the potential for use of the selective separation and preconcentration of $\mathrm{Au}$ from the sample matrix in strong media.

\section{Optimization of Elution Conditions}

To choose a suitable eluent for the quantitative recovery of $\mathrm{Au}$ from the column, several eluent solutions, including $\mathrm{KSCN}$ (at $\mathrm{pH}$ 2), $0.25 \mathrm{~mol} \mathrm{~L}^{-1} \mathrm{Na}_{2} \mathrm{~S}_{2} \mathrm{O}_{3}, 10 \%$ $\mathrm{NH}_{3} \cdot \mathrm{H}_{2} \mathrm{O}$, and $1.0 \%$ thiourea and $1.0 \%$ thiourea in $0.12 \mathrm{~mol} \mathrm{~L}^{-1} \mathrm{HCl}$, were tested as the elution solution to elute Au from the microcolumn. The results are presented in Table II. As can be seen, maximum recovery (about 97\%) was obtained using $1.0 \%$ thiourea in $0.12 \mathrm{~mol} \mathrm{~L}^{-1} \mathrm{HCl}$, but incomplete elution of $\mathrm{Au}$ was observed for all other solutions. In addition, we determined the effect of eluent volume on the recovery percent of Au, shown in Table II. The results indicate that $5.0 \mathrm{~mL}$ of $1.0 \%$ thiourea in $0.12 \mathrm{~mol} \mathrm{~L}^{-1} \mathrm{HCl}$ was sufficient for the quantitative elution of adsorbed gold from the ESM microcolumn. Therefore, $5.0 \mathrm{~mL}$ of the eluent was selected as the volume used for further study.

\section{Effect of the Eluent and Sample Flow Rates}

The flow rate of the sample solution affects Au separation, preconcentration efficiency, and analysis time. Using a 50-mL sample solution containing $1.0 \mu \mathrm{g} \mathrm{L} \mathrm{L}^{-1} \mathrm{Au}$, the effect of the sample flow rate was studied in the range of $0.5-4.0 \mathrm{~mL}$ $\min ^{-1}$. As show in Figure 3, the experimental results indicate that the recovery rates were higher than

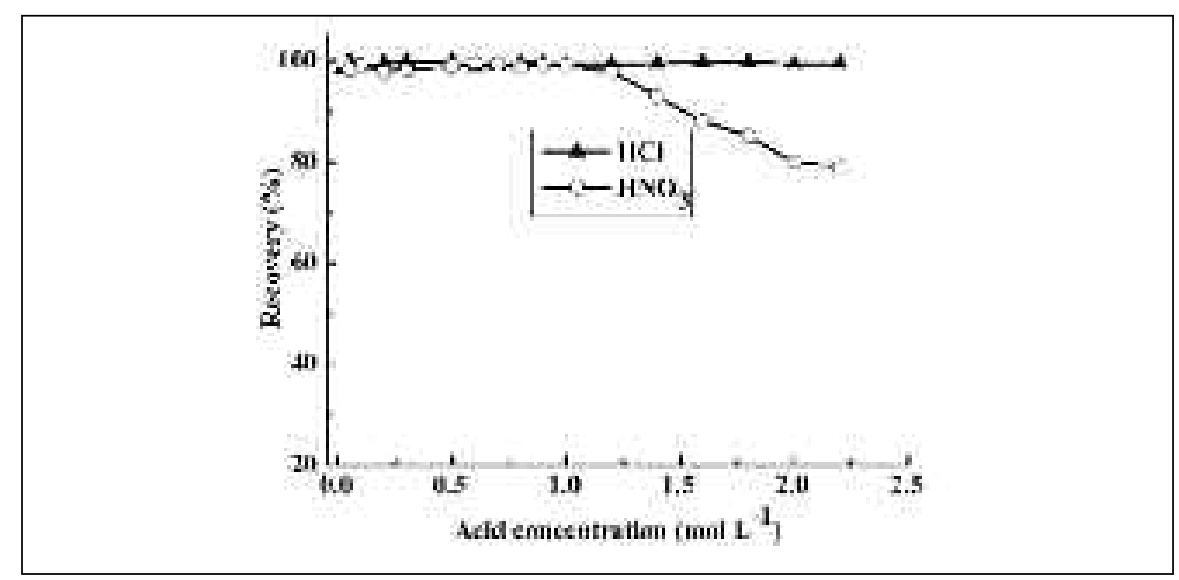

Fig. 2. Effect of acid concentration on the adsorption of Au with ESM.

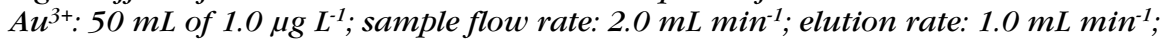
elution volume: $5.0 \mathrm{~mL}$; ESM amount: $120 \mathrm{mg}$.

TABLE II

Percent Recovery of Gold from ESM as a Function of Stripping Solution and Volume

\begin{tabular}{lcccc}
\hline & \multicolumn{4}{c}{$\%$ Recovery } \\
\cline { 2 - 5 } Eluent Agent & First & Second & Third & \\
& $2.5 \mathrm{~mL}$ & $2.5 \mathrm{~mL}$ & $2.5 \mathrm{~mL}$ & Total \\
& 38 & 27 & 9 & 74 \\
\hline $10 \% \mathrm{KSCN}$ in pH 2.0 & 43 & 17 & 11 & 71 \\
$5 \% \mathrm{Na}_{2} \mathrm{~S}_{2} \mathrm{O}_{3}$ & 23 & 15 & 15 & 53 \\
$10 \% \mathrm{NH}_{3} \cdot \mathrm{H}_{2} \mathrm{O}$ & 74 & 12 & 3 & 89 \\
$1.0 \%$ thiourea & 86 & 12 & 2 & 100 \\
$0.5 \%$ thiourea in $0.12 \mathrm{~mol} \mathrm{~L}^{-1} \mathrm{HCl}$ & 95 & 5 & - & 100 \\
$1.0 \%$ thiourea in $0.12 \mathrm{~mol} \mathrm{~L}^{-1} \mathrm{HCl}$ & 95 & 3 & - & 100 \\
$2.0 \%$ thiourea in $0.12 \mathrm{~mol} \mathrm{~L}^{-1} \mathrm{HCl}$ & 97 & & & \\
\hline
\end{tabular}




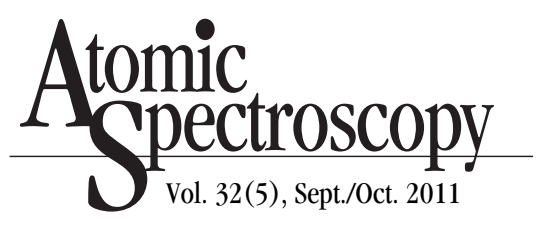

$95 \%$ for a sample solution flow rate of $0.5-3.0 \mathrm{~mL} \mathrm{~min}^{-1}$. When the sample flow rates are higher than $3.0 \mathrm{ml} \mathrm{L}^{-1}$, the recovery of $\mathrm{Au}$ decreases slightly, which may be due to less chance for Au adsorption. Thus, a sample flow rate of $2.0 \mathrm{~mL} \mathrm{~min}{ }^{-1}$ was selected for adsorption in this work. In addition, the flow rate of the eluent was chosen as $1.0 \mathrm{~mL} \mathrm{~min}{ }^{-1}$ in all experiments.

\section{Effects of ESM Amount}

To achieve quantitative recovery of gold ions in SPE, the amount of ESM ranging from 60 to $200 \mathrm{mg}$ was investigated in $50 \mathrm{~mL}$ of $1.0 \mu \mathrm{g} \mathrm{L}^{-1}$ gold-ion solution. The results are shown in Figure 4. As can be seen, there were no obvious effects on the recovery of gold in the ESM amounts from 90 to $200 \mathrm{mg}$. Therefore, $120 \mathrm{mg}$ of ESM was selected as the optimal amount for subsequent studies.

\section{Breakthrough Volume}

In the analysis of real samples, the breakthrough volume is one of the key parameters influencing separation and preconcentration. Aliquots of 50-1200 mL of $1.2 \mathrm{~mol} \mathrm{~L}^{-1} \mathrm{HCl}$ solutions containing $0.10 \mu \mathrm{g}$ of gold standard were designed to test the effect of breakthrough volume on the recovery of Au. The above solutions were passed through the microcolumn according to the recommended procedure. The final volume of eluent was fixed at $5.0 \mathrm{~mL}$ in all cases. It was found that quantitative recovery ( $>95 \%$ ) was obtained when the sample volume reached $800 \mathrm{~mL}$. The preconcentration factor (PF), calculated as the ratio of the highest breakthrough volume to the lowest final volume, was found to be 160 for Au when the final volume was $5.0 \mathrm{~mL}$.

\section{Adsorption Capacity}

The maximum capacity of the eggshell membrane was determined by passing solutions containing $10 \mathrm{mg} \mathrm{L}^{-1} \mathrm{Au}$ in $1.2 \mathrm{~mol} \mathrm{~L}^{-1} \mathrm{HCl}$ with $120 \mathrm{mg}$ of ESM at a flow rate of

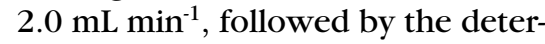
mination of retained metal ions using ICP-MS. The results show that the maximum capacity of the eggshell membrane was $8.3 \mathrm{mg} \mathrm{g}^{-1}$ of Au.

\section{Reuse of ESM Microcolumn}

The reuse of an ESM microcolumn in SPE was tested by repetitive use for more than one sample. After the elution step, the microcolumn must be prepared for subsequent sample enrichment. Regenerated with $5 \mathrm{~mL}$ of $1.0 \%$ thiourea $0.12 \mathrm{~mol} \mathrm{~L}^{-1} \mathrm{HCl}$ solution and $30 \mathrm{~mL}$ of deionized water, the microcolumn packed with the same ESM can be repetitively used 20 times without an obvious decrease in the recoveries of the target ions.

\section{Effect of Matrix Ions}

The effect of various ions on the separation and determination of $1.0 \mu \mathrm{g} \mathrm{L}^{-1}$ gold was studied. The tolerance limit of coexisting ions is defined as the ion concentration causing a relative error of less than $\pm 5 \%$. In this study, the transitionand heavy-metal ions, such as $\mathrm{Cu}^{2+}$, $\mathrm{Cd}^{2+}, \mathrm{Pb}^{2+}, \mathrm{Zn}^{2+}, \mathrm{Co}^{2+}, \mathrm{Ni}^{2+}, \mathrm{Cr}^{3+}$, and $\mathrm{Fe}^{3+}$ were scarcely adsorbed on the eggshell membrane in $1.2 \mathrm{~mol} \mathrm{~L}^{-1}$ $\mathrm{HCl}$. This indicated that the adsorption of these metal ions was negligible.

Gold was detected using the ${ }^{197} \mathrm{Au}^{+}$isotope signal in the ICP-MS methods. It was subject to potential interferences from polyatomic ions for type ${ }^{197}\left[{ }^{180} \mathrm{Hf}^{16} \mathrm{O}^{1} \mathrm{H}^{+}\right]$and ${ }^{197}\left[{ }^{181} \mathrm{Ta}^{16} \mathrm{O}^{+}\right]$in the plasma. These interferences can be eliminated by separation of Au from the matrix. Since Hf and Ta were not retained on the ESM column, zero signals of ${ }^{180} \mathrm{Hf}$ and ${ }^{181} \mathrm{Ta}$ were recorded for

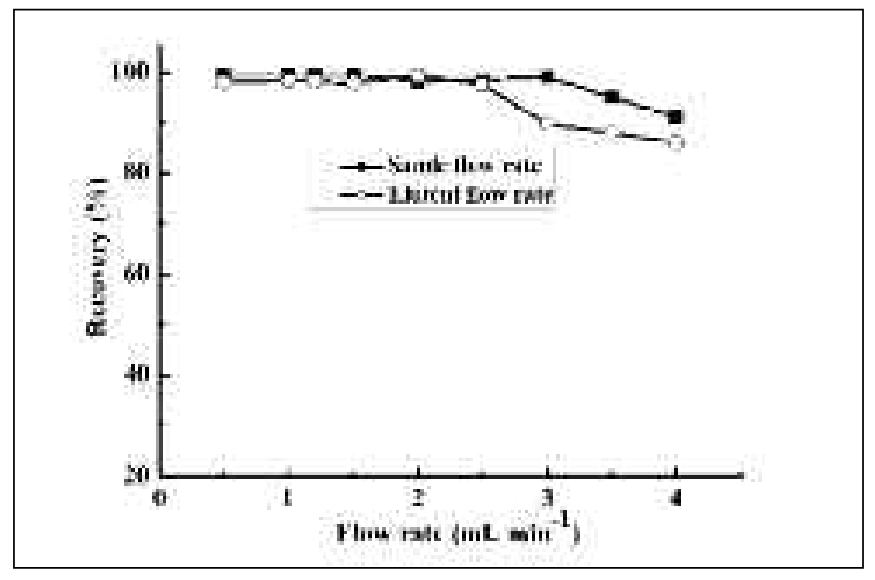

Fig. 3. Effect of solution flow rate on Au adsorption with ESM. $1.0 \mu \mathrm{g} \mathrm{L}^{-1} \mathrm{Au}^{3+}$ in $1.2 \mathrm{~mol} \mathrm{~L}^{-1} \mathrm{HCl}$; elution volume: $5.0 \mathrm{~mL}$; ESM amount : $120 \mathrm{mg}$.

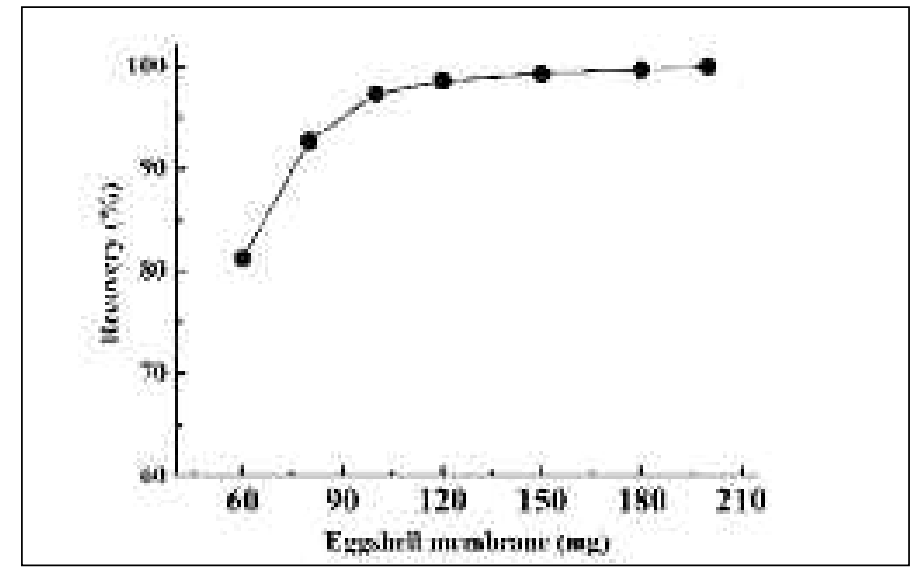

Fig. 4. Effect of ESM amount on Au recovery. 
these masses. The results obtained are shown in Table III. The result shows that most common ions did not interfere in the determination, and the method is highly selective in the presence of matrix ions.

\section{Analytical Performance of the Method}

Under the optimal experimental conditions described above, the calibration curve for Au was linear over the concentration range of 0.01-500 $\mu \mathrm{g} \mathrm{L}^{-1}$. Good linearity was obtained, with a correlation coefficient $\left(r^{2}\right)$ of 0.9995 . According to the $3 \sigma$ criterion, the detection limit (in $1.0 \%$ thiourea $-0.12 \mathrm{~mol} \mathrm{~L}^{-1} \mathrm{HCl}$ blank solution, $\mathrm{n}=11$ ) was $0.92 \mathrm{ng} \mathrm{L}^{-1}$ for Au using ICP-MS. The precision of this method (RSD), examined by 11 replicate measurements of $1 \mu \mathrm{g} \mathrm{L} \mathrm{L}^{-1}$ Au model solutions, was $0.83 \%$.
Table IV compares the characteristic data of the present method with literature data for gold determination using SPE in terms of the enrichment factor and the detection limits. From the data shown in Table IV, the proposed method is better than the FAAS methods reported in $(13,16,19,43)$ in terms of detection limit and sensitivity. References (18 and 22) reported better detection limits because the sample volumes were 2.5 L and 5.0 L. Generally, the enrichment factor obtained by the present method is comparable to those reported methods. The higher enrichment factor reported in (18) was obtained using $2.5 \mathrm{~L}$ of sample solution. The adsorption acidity and range was better than those reports.

TABLE III

Effect of Coexisting Ions in the Determination of $1.0 \mu \mathrm{g} \mathrm{L}^{-1}$ of Gold

\begin{tabular}{lc}
\hline Coexisting Ions & Tolerance Limit $\left(\mathrm{mg} \mathrm{L}^{-1}\right)$ \\
\hline $\mathrm{K}^{+}, \mathrm{Na}^{+}, \mathrm{Li}^{+}, \mathrm{Ca}^{2+}, \mathrm{Mg}^{2+}$ & 6,000 \\
$\mathrm{Cu}^{2+}, \mathrm{Cd}^{2+}, \mathrm{Pb}^{2+}, \mathrm{Zn}^{2+}, \mathrm{Co}^{2+}, \mathrm{Ni}^{2+}, \mathrm{Mn}^{2+}, \mathrm{Ti}^{3+}$ & 500 \\
$\mathrm{Cr}^{3+}, \mathrm{Fe}^{3+}, \mathrm{Al}^{3+}$ & 600 \\
$\mathrm{Cl}^{-}, \mathrm{Br}^{-}, \mathrm{NO}_{3}^{-}$ & 5,000 \\
$\mathrm{PO}_{4}^{3-}, \mathrm{SO}_{4}^{2-}$ & 1000 \\
$\mathrm{Pd}^{2+}, \mathrm{Pt}^{4+}, \mathrm{Tl}^{3+}$ & 60 \\
$\mathrm{Hf}(\mathrm{IV}), \mathrm{Ta}(\mathrm{V}), \mathrm{REE}$ & 25 \\
\hline
\end{tabular}

\section{Validation and Applications}

To establish the validity of the proposed analytical procedure, the method was applied to the determination of gold in the geological certified reference materials GBW07244, GBW07246, and GBW07293. The analytical results are summarized in Table V. As can been seen, there is a good agreement with the certified values. These results demonstrate the applicability of ESM for separation and preconcentration in a microcolumn prior to ICP-MS for the interference-free determination of trace $\mathrm{Au}$ in the geological samples.

The overall relative standard deviation (RSD) of the proposed solid-phase extraction procedure was below $1.53 \%$ (for $n=3$, i.e., three individual separation and preconcentration procedures). In addition, the recoveries for the addition of a gold standard solution to the samples after spiking the sample solution with $0.02 \mu \mathrm{g} \mathrm{g}^{-1}$ gold standard was in the range of 98.7-101.3\%.

\section{CONCLUSION}

A new method has been developed using the eggshell membrane (ESM) as the sorbent for solid-phase extraction of trace gold and its determination by inductively cou-

Comparison of Present Method With Other SPE Methods

\begin{tabular}{|c|c|c|c|c|c|}
\hline Adsorbent & Method & Medium & $\mathrm{PF}^{\mathrm{a}}$ & $\mathrm{DL}\left(\mu \mathrm{g} \mathrm{L}^{-1}\right)^{\mathrm{b}}$ & Reference \\
\hline $\begin{array}{l}\text { Dowex M } 4195 \\
\text { chelating resin }\end{array}$ & FAAS & pH 2.0-8.0 & 31 & 1.61 & (13) \\
\hline Amberlite XAD-2000 & FAAS & $2.0 \mathrm{~mol} \mathrm{~L}^{-1} \mathrm{HNO}_{3}, 0.1 \% \mathrm{DDTC}$ & 200 & 16.6 & (43) \\
\hline MWNT & AAS & pH $1.0-6.0$ & 75 & 0.15 & (16) \\
\hline MWCNT/NBHAE & AAS & pH $2.0-7.5$ & 250 & 0.03 & $(44)$ \\
\hline Modified silica & AAS & $\mathrm{pH} 2.0-4.0$ & 800 & $0.06 \mathrm{ng} \mathrm{L}^{-1}$ & (18) \\
\hline Nanometer $\mathrm{TiO}_{2}$ & FAAS & $\mathrm{pH} 8.0-10.0$ & 50 & 0.21 & (19) \\
\hline Thiol cotton fibre & GFAAS & pH1.5-2.0 & - & $0.02 \mathrm{ng} \mathrm{L}^{-1}$ & (22) \\
\hline Tree leaf powder & ICP-OES & $\mathrm{pH} 3.0-5.0$ & 50 & 0.047 & (23) \\
\hline Eggshell membrane & ICP-MS & $0.01-2.4 \mathrm{~mol} \mathrm{~L}^{-1} \mathrm{HCl}, \mathrm{pH} 0.0-5.0$ & 160 & $0.92 \mathrm{ng} \mathrm{L}-1$ & This work \\
\hline
\end{tabular}

${ }^{\mathrm{a}}$ Preconcentration factor, ${ }^{\mathrm{b}}$ detection limit. 
TABLE $V$

Analytical Results for Gold in Geological Certified Reference Materials (mean $\pm \sigma, \mathbf{n}=\mathbf{3}$ )

\begin{tabular}{lll}
\hline Sample & \multicolumn{2}{c}{ Conc. of $\mathrm{Au}\left(\mathrm{ng} \mathrm{g}^{-1}\right)$} \\
\cline { 2 - 3 } & Certified & \multicolumn{1}{c}{ Found } \\
\hline GBW 07244 & $5.3 \pm 0.2$ & $5.4 \pm 0.2$ \\
GBW 07246 & $21.6 \pm 1.1$ & $21.6 \pm 0.9$ \\
GBW 07293 & $45.0 \pm 2.0$ & $45.1 \pm 1.1$ \\
\hline
\end{tabular}

pled plasma mass spectrometry (ICP-MS). The method provides highly selective adsorption for trace gold ions in $\mathrm{HCl}$ solutions. Chicken eggshell membranes show good potential for the separation and preconcentration of gold from geological samples. Compared with the conventional ion-exchange resin, modified silica gel, nanometer materials, etc. the eggshell membrane is not only a green and environmentally friendly sorbent but is also abundant, effective, and inexpensive. A low cost method with good sensitivity and selectivity was successfully applied to the determination of trace gold in geological samples with satisfactory results.

\section{ACKNOWLEDGMENTS}

This work was supported by the Hubei Provincial Natural Science Foundation of China (No. 2008CDA100) and the Geological Survey of China (No. 1212011120266).

Received June 24, 2011.

\section{REFERENCES}

1. L.J. Cabri, Mineral. Mag. 56, 289 (1992).

2. S.Z. Chen, M.F. Xiao, D.B. Lu, Z.X. Hu and X.L. Zhan, At. Spectrosc. 28, 90 (2007).

3. M.S. El-Shahawi, A.S. Bashammakh, and S.O. Bahaffi, Talanta 72, 1494 (2007).
4. L. Kocúrová, I. S. Balogh, J. Škrlíková, J. Posta, and V. Andruch, Talanta 82, 1958 (2010).

5. D. Afzali, A. Mostafavi, and M. Mirzaei, J. Hazard. Mater. 181, 957 (2010).

6. K. Pyrzyńska, Spectrochim. Acta Part B 60, 1316 (2005).

7. P. Roy, V. Balaram, S. Sawant, K.S.V. Subramanyam, M. Satyanarayan, K.Vani, and K. Srivalli, At. Spectrosc. 31, 35 (2010).

8. Z. Li, J. Anal. At. Spectrom. 21, 435 (2006).

9. X. Z. Cheng, K. Shao, R.H. Zhang, Y. S. Zhang, and Y. Liu, At. Spectrosc. 30, 98 (2009).

10. V. Camel, Spectrochim. Acta Part B 58, 1177 (2003).

11. A. Tunceli, and A. R. Turker, Analyst 122, 239 (1997).

12. Y. W. Wu, Z.C. Jiang and B. Hu, Geostand. Geoanal. Res. 28, 383 (2004).

13. I. Timur, B. F. Senkal, O. Kaplan, G. Kaya, C. Ozcan, N. M. Karaaslan, and M. Yaman, At. Spectrosc. 30, 190 (2009).

14. G. Chakrapani, P.L. Mahanta, D.S.R. Murty, and B. Gomathy, Talanta 53, 1139 (2001).

15. N. Burham, Desalination 249, 1199 (2009).

16. X. Cheng, S. Chen, X. Wang, and C. Liu, At. Spectrosc. 31, 75 (2010).

17. P. Liang, E. Zhao and R. Liu, Geostand. Geoanal. Res. 33, 63 (2009)

18. D.H. Chen, M. He, C.Z. Huang, and B.Hu, At. Spectrosc. 29, 165 (2008)

19. R. Liu, and P. Liang, Anal. Chim. Acta, 604, 114 (2007).

20. H.Y. Wang, S.H. Qian, S.B. Mo and G.Q. Huang, Chin. J. Anal. Chem. 33, 198 (2005).

21. A.M. Thomas and D.S.R. Murty, At. Spectrosc. 29, 69 (2008).

22. M. Yu, D. Sun, R. Huang, W. Tian, W. Shen, H. Zhang, and N. Xu, Anal. Chim. Acta 479, 225 (2003).

23. S.S. Jibrin, C.Z. Huang, J. Li, N. Zhang and $\mathrm{B}$. Hu, Geostand. Geoanal. Res. 33, 469 (2009).

24. X.W. Chen, L.L. Huang, and R.H. He, Talanta 78, 71 (2009).

25. W.T. Tsai, J.M. Yang, C.W. Lai, Y.H. Cheng, C.C. Linand, and C.W. Yeh, Bioresour. Technol. 97, 488 (2006).
26. S.I. Ishikawa, K. Suyama, K. Arihara, and M. Itoh, Biol. Trace Elem. Res. 86, 227(2002).

27. K. Chojnacka, J. Hazard. Mater. 121, 167 (2005).

28. R. Shoji, T. Miyazaki, T. Niinou, M. Kato, and H. Ishil, J. Mater. Cycles Waste Manag. 6, 142 (2004).

29. M. Arami, N.Y. Limaee, and N.M. Mahmoodi, Chemosphere 65, 1999 (2006).

30. C.S. Pundir, M. Bhambi, and N.S. Chauhan, Talanta 77, 1688 (2009).

31. D. Xiao, and M.M. F. Choi, Anal. Chem. 74, 863 (2002)

32. B.Z. Zheng, L. Qian, H.Y. Yuan, D. Xiao, X.P. Yang, M. C. Palau, and M.F. Choi, Talanta 82, 177(2010).

33. Q. Dong, H. Su, D. Zhang, N. Zhub and X. Guo, Scripta Mater. 55, 799 (2006) 7.

34. Y.J. Zhang, W.D. Wang, L. Li, Y.M. Huang, and J. Cao, Talanta, 80, 1907 (2010).

35. A.M. Zou, X.W. Chen, M.L. Chen and J.H. Wang, J. Anal. At. Spectrom. 23, 412 (2008).

36. Y. Dauphin, J.P. Cuif, M. Salome, J. Susini and C. T. Williams, Anal. Bioanal. Chem. 386, 1761 (2006).

37. Y. Nys, J. Gautron, M.D. McKee, J.M. Gautron and M.T. Hincke, World's Poultry Sci. J. 57, 401 (2001).

38. W. Chen, B. Li, C. Xu and L.Wang, Biosens. Bioelectron. 24, 2534 (2009).

39. D.L. Pavia, G.M. Lampman, and G.S. Kaiz, Introduction to Spectroscopy: A Guide for Students of Organic Chemistry. W.B. Saunders Company. 1987

40. R.G. Pearson, J. Am. Chem. Soc. 85, 3533 (1963).

41. B.C. Starcher and C. S. King, Connect. Tissue Res. 8, 53 (1980).

42. D.A. Carrino, J.E. Dennis, T.M. Wu, J.L. Arias, M.S. Fernandez, J.P. Rodriguez, D.J. Fink, A.H. Heuer and A. I. Caplan, Connect. Tissue Res. 35, 325 (1996).

43. H.B. Senturk, A. Gundogdu, V. N. Bulut, C. Duran, M. Soylak, L. Elci, and M. Tufekci, J. Hazard. Mater. 149, 317 (2007)

44. T. Shamspur and A. Mostafavi, J. Hazard. Mater. 168, 1548 (2009). 